\title{
Farmer awareness, coping mechanisms and economic implications of coffee leaf rust disease in Uganda
}

\author{
H. Luzinda ${ }^{1}$, M. Nelima ${ }^{1}$, A. Wabomba ${ }^{1}$, A. Kangire ${ }^{1}$, P.C. Musoli ${ }^{1}$ and R. Musebe ${ }^{2}$ \\ ${ }^{1}$ National Coffee Research Institute (NaCORI)/National Agricultural Research Organization (NARO) \\ P. O. Box 185 Mukono, Uganda \\ ${ }^{2}$ CABI Africa Regional Center, P. O. Box 633-00621, Village Market, Nairobi, Kenya
}

Author for correspondence: luzindaharris2001@yahoo.com

\begin{abstract}
Coffee leaf rust (CLR) still remains a serious threat to the economics of coffee farming in Uganda. The disease is more severe on Arabica coffee (Coffea arabica) at mid and low altitude (1500 $\mathrm{m}$ and below) where crop losses is up to $50 \%$. The objective of this study was to document farmers' knowledge about the disease, economic implications and coping strategies across the Arabica growing zones in Uganda. A stratified random sampling procedure was adopted. The main data collection tool was a semi-structured questionnaire for face-to-face interview and checklist for focus group discussions (FGDs). SPSS for windows (Version 16) was used for statistical analysis. Overall, $83.8 \%$ had knowledge on the disease. The disease reportedly causes premature defoliation and loss of photosynthetic surfaces, leading to appearance of pale yellow spots on the lower surface of the leaves $\mathbf{( 7 2 . 3 \%}$ ) and expanding berries failing to fill up and young berries shedding off $(11.5 \%)$. The most susceptible variety reported was SL14; while KP423 was reportedly tolerant. Results further revealed that rust incidence led to a significant $(p \leq 0.01)$ reduction in Arabica coffee productivity and income by $49.5 \%$. As cope up strategies, farmers practiced timely weeding $(\mathbf{8 1 . 5 \%})$, chemical spraying mainly using Bordeaux mixture $(\mathbf{2 0 . 8 \%})$, phyto-sanitary methods $(8.1 \%)$, concoctions $(10.4 \%)$, fertiliser application $(12.4 \%)$ and planting tolerant varieties $(9.2 \%)$. The use of concoctions and phyto-sanitary methods significantly $(P \leq 0.01)$ reduced the impact of the disease on annual production per ha by 1139 and $1255 \mathrm{~kg}$, respectively.
\end{abstract}

Key words: Coffee Leaf Rust, Indigenous knowledge, economic implication, Uganda

\section{Introduction}

Coffee Leafrust causes Arabica coffee trees to shed their leaves, resulting in fewer beans, of inferior quality (Rutherford and Phiri, 2006). Leaves turn into pale-yellow on the surface and orange beneath and eventually shed off (Kushalappa, 1989), leading some beans to fall off while others are malformed and lighter because the pods are not filled properly (Small, 1928). This damage leads 
to stunted bushes, which are low yielding and usually die after a few years (Avelino et al., 2004). As a cope up strategy, farmers practiced different control options. The objective of this study was to document; farmer indigenous knowledge about the disease and their control strategies, information on the economic implications of the CLR in Uganda.

\section{Materials and methods}

\section{Study area}

The study was conducted in 2009 in the major Arabica coffee growing regions of Uganda; Mt. Elgon region (Kapchorwa and Sironko districts) which borders with Kenya, and West-Nile region (Nebbi district) which borders Democratic Republic of Congo (DRC). The Mt. Elgon area lies between latitudes $1^{\circ} 17^{\prime} \mathrm{N}$ and $0^{\circ} 51^{\prime} \mathrm{N}$ and longitude $34^{\circ} 13^{\prime} \mathrm{E}$ and $34^{\circ}$ $25^{\prime} \mathrm{E}$, at an altitude of $1288-2135$ meters above sea level (van Asten et al., 2011). In Nebbi district, the study area lies between latitudes $2^{\circ} 14^{\prime} \mathrm{N}$ and $2^{\circ} 46^{\prime} \mathrm{N}$ and longitudes $30^{\circ} 76^{\prime} \mathrm{E}$ and $31^{\circ} 52^{\prime} \mathrm{E}$, at an altitude of 1450-1800 $\mathrm{m}$ above sea level. Mt Elgon region receives mean annual rainfall of more than $1520 \mathrm{~mm}$; while West-Nile receives $1100 \mathrm{~mm}$, following a bimodal pattern in both regions. Temperatures at both locations range between $15^{\circ}-30{ }^{\circ} \mathrm{C}$ throughout the year.

\section{Sampling and data collection}

A stratified random sampling procedure was adopted, where in each district, two sub-counties were purposively selected. From each of the sub-counties, two parishes were randomly chosen and in each of these four villages were selected and subsequently in each village four small holder coffee farm households were surveyed. Sampling and mobilisation of coffee farmers was done with the help of district coffee coordinators, sub county NAADS coordinators and Local Council (L.C.) 1 village chairpersons.

The main data collection tool was a semi-structured questionnaire, designed to capture information on farmers' socioeconomic status, farming systems and effect of CLR infestation. A total of 173 small holder farmers were interviewed. The questions focused on the change in productivity due to CLR infestation, farmer's indigenous knowledge about the disease and their control strategies. The questionnaire was administered in a faceto-face interview, with farmers, mainly household heads as the respondents. A checklist was developed and used for focus group discussion (FGD). One FGD consisting of $15-20$ individuals was involved in the study per district. Specifically, FGDs involved the district coffee coordinator, district production officer, extension staff, local council political leaders, leaders from the district farmers association, prominent coffee farmers and coffee dealers. Results from the FGD were used as a check list to the individual responses, and for easier interpretation of the farming systems of the respective district communities.

\section{Data analysis}

Completed questionnaires were edited, coded and data entered into Ms Excel for cleaning. Thereafter data were transferred to the Statistical Package for Socio Sciences(SPSS) for windows (Version 16) for statistical analysis. K-S tests were run to check for normal distribution of the variables, after which inferential and descriptive statistics were used to summarise farmers' responses 
into percentages, averages and graphical representation. Mean scores for the effectiveness of various control methods against CLR as reported by farmers were determined by averaging the score of each control method. Linear Regression at 5\% probability level, was used to understand the influence of farmers coping mechanism on CLR Impact on productivity and income (Armstrong and Eperjesi, 2001; Nyeko et al., 2002)

\section{Results}

\section{Coffee production}

The household agricultural land planted with coffee varied from 0.1 to 4.4 ha with an average of 0.6ha and 2,370 Arabica coffee trees. Most farmers (59\%) reported intercropping coffee with mainly banana and planting it under tree shades. SL14 variety was the most commonly grown $(45 \%)$. Main inputs used in coffee production were manure $(66.5 \%)$, inorganic fertiliser $(20.8 \%)$, agro chemicals $(19.7 \%)$, pruning saw/ secateurs (93.2\%), and hired labour (4\%). Households spent between US $\$ 16$ and US\$ 575, with an average of approximately US\$ 45 on inputs per annum $\mathrm{ha}^{-1}$. Average annual yield (parchment ha-1) was $432 \mathrm{~kg}(88.4 \%)$

\section{Farmer indigenous knowledge and economic implications of CLR}

Overall, $83.8 \%$ were aware of symptoms of the CLR and mostly identified it with premature defoliation and loss of photosynthetic surfaces. A total of $72.3 \%$ cited appearance of pale yellow spots on the lower leaf surfaces of the leaves; while $11.5 \%$ reported that expanding berries did not fill up and young berries were shed off. Most farmers $(26 \%)$ perceived the disease to be spread by wind (3.5\%) water runoff $(8.7 \%)$ human and insect activity (20\%) and, movement of infected plant material. While $76.3 \%$ reported CLR incidence to be more prevalent during the dry season and $6.4 \%$ reported rainy/wet weather. About $2.9 \%$ could not tell the mode of spread of the disease.

Variety SL14 was reported as most susceptible while variety KP423 tolerant to CLR (Table 1). However, due to the incidence of the disease, up to $88.4 \%$ of the farmers reported that repeated attacks of rust led to decline of the coffee bush, reducing average annual yield per hectare from 855 to $432 \mathrm{~kg}$ which is a $49.5 \%$ fall in productivity and income, and a subsequent gradual loss of Arabica coffee trees (Table 2). Results further indicate that, without CLR in the farmer's garden, $63 \%$ reported a moderate reduction in income from other crops, mainly food crops and a subsequent moderate increase with CLR in the farmers' garden (87.2\%). When coffee is affected by CLR, $59.5 \%$ of the farmers reported a large reduction in consumption of basic needs, $55.5 \%$ moderate reduction in expenditure on social obligations and entertainment, $47.4 \%$ large reduction in investment and 59\% moderate reduction in hiring farm labor. This elucidates the importance of coffee as income security crop (Table 3 ).

\section{Coping mechanisms for CLR}

Majority of the respondents interviewed had attempted to control CLR as a coping strategy (Table 4). Farmers claimed to have used a wide range of control practices; including timely weeding $(81.5 \%)$, chemicals mainly Bordeaux mixture (20.8\%) because they desperately wanted to eradicate the fungus, Phytosanitary methods $(8.1 \%)$, and using concoctions mainly a mixture of urine, ash and pawpaw or mango leaves applying to 
Table 1. Farmer indigenous knowledge about coffee leaf rust disease in Uganda

Variable $\quad \mathrm{N} \quad \begin{gathered}\text { Percentage of } \\ \text { farmers reporting }\end{gathered}$

\section{Knowledge on symptoms of CLR}

a) Premature shading of leaves

b) Leaves turn to pale yellow/ orange/ rust/ golden colour at the lower surface

c) White powdery mass on leaves

d) Drying of coffee tree/bush

e) Coffee berries fail to ripe

Trend of disease occurrence
a) Increasing
b) Constant
c) Decreasing

Mode of transmission of CLR

a) Wind $\quad 45 \quad 26.0$

b) Infected plant to non infected garden $\quad 35 \quad 20.2$

c) Human and animals activity $\quad 15 \quad 8.7$

d) Water run off

Field conditions with severity

a) Unshaded coffee trees $\quad 122 \quad 70.5$

b) Unweeded coffee garden $\quad 101 \quad 58.4$

c) Unpruned coffee $\quad 93 \quad 53.8$

d) Less fertile parts of the farm $\quad 91 \quad 52.6$

Season of the year CLR severity

a) Dry season $\quad 132 \quad 76.3$

b) Rain/wet season $\quad 11 \quad 6.4$

c) Indifferent (all seasons throughout the year) $\quad 6 \quad 2.9$

Varieties most affected by CLR on the farm

a) Improved variety (mainly SL 14) $\quad 89 \quad 51.4$

b) Local/traditional variety $\quad 30 \quad 17.3$

\section{Varieties least affected by CLR on the farm}
a) Local variety
81
46.8
b) Improved variety (mainly KP423)

$\mathrm{N}=$ Total number of responses 
Table 2. Production (kgs of parchment / ha/ year) and income with CLR and without CLR in the farmer's garden in Uganda

\begin{tabular}{lllll}
\hline Category & $\mathrm{N}$ & Without CLR & With CLR & T-test \\
\hline $\begin{array}{l}\text { Average area (ha) } \\
\begin{array}{l}\text { Average quantity produced } \\
\text { (kgs of parchment) }\end{array}\end{array}$ & 168 & $3.90(3.82)$ & $3.85(3.75)$ & $0.05^{\mathrm{NS}}$ \\
Average Income (US\$) & 153 & $855(498.72)$ & $432(156.71)$ & $4.24^{* * *}$ \\
\hline
\end{tabular}

$\mathrm{N}=$ Total number of respondents. Figures in parenthesis are standard deviation; $*, * *, * * *$ implies statistically significant differences between means at $10 \%, 5 \%$ and $1 \%$ levels of significance, respectively; NS implies not significant; Parchment refers to unprocessed coffee

\section{Table 3. Household economic implications of CLR}

\begin{tabular}{lcc}
\hline Magnitude of change in variable & $\begin{array}{r}\text { Without CLR in the } \\
\text { farmer's garden }(\%)\end{array}$ & $\begin{array}{c}\text { With CLR in the farmer's } \\
\text { garden }(\%)\end{array}$
\end{tabular}

\section{Income from other crops}

$\begin{array}{lrr}\text { a) Moderate reduction } & 63.0 & 2.8 \\ \text { b) Large reduction } & 15.0 & 4.0 \\ \text { c) Constant } & 8.1 & 6.0 \\ \text { d) Moderate increase } & 3.9 & 87.2\end{array}$

\section{Expenditure on basic needs}
a) Moderate reduction
b) Large reduction
c) Constant
d) Moderate increase

Expenditure on socio obligations
a) Moderate reduction
b) Large reduction
c) Constant
19.7
d) Moderate increase

Expenditure on investment

$\begin{array}{lr}\text { a) Moderate reduction } & 37.0 \\ \text { b) Large reduction } & 47.4 \\ \text { c) Constant } & 5.8 \\ \text { d) Moderate increase } & .6\end{array}$

\section{Expenditure on hiring farm labour}
a) Moderate reduction
b) Large reduction
c) Constant
d) Moderate increase

Magnitude of change was scored as follows: $-50 \%$ and above=Large reduction, $-0.1--50 \%=$ Moderate reduction, $0 \%=$ Constant, $0.1-50 \%=$ Moderate increase, $50 \%$ and above $=$ Large increase 
Table 4. Farmers' control methods for CLR and their effectiveness in Uganda

\begin{tabular}{lcr}
\hline Control method & $\begin{array}{c}\text { Effectiveness } \\
\text { (mean scores) }\end{array}$ & $\%$ \\
\hline a) Constant weeding( hoe, hand plucking and spraying herbicides) & 1.92 & 81.5 \\
b) Fertiliser application & 1.86 & 21.4 \\
c) Chemicals(mainly Bordeaux mixture) & 1.96 & 20.8 \\
d) Concoctions( urine, red pepper, ash and pawpaw or mango leaves) & 1.51 & 10.4 \\
e) Planted tolerant varieties & 2.11 & 9.2 \\
f) Phyto-sanitary methods & 2.42 & 8.1 \\
\hline
\end{tabular}

$\mathrm{N}=$ Total number of responses. Effectiveness of control methods were scored as follows: $0=$ not effective, 1 = low effective, 2 = moderate effective, 3 = highly effective

Table 5. Influence of farmers' control method on CLR impact on coffee productivity in Uganda

\begin{tabular}{|c|c|c|c|c|c|c|c|}
\hline \multirow[t]{2}{*}{ Model } & \multicolumn{2}{|c|}{$\begin{array}{l}\text { Unstandardised } \\
\text { coefficients }\end{array}$} & \multirow{2}{*}{$\begin{array}{l}\text { Standardised } \\
\text { coefficients } \\
\text { Beta }\end{array}$} & \multirow[t]{2}{*}{$\mathrm{t}$} & \multirow[t]{2}{*}{ Sig. } & \multicolumn{2}{|c|}{$\begin{array}{l}95 \% \text { Confidence } \\
\text { Interval for } \mathrm{B}\end{array}$} \\
\hline & $\mathrm{B}$ & $\begin{array}{l}\text { Std. } \\
\text { Error }\end{array}$ & & & & $\begin{array}{l}\text { Lower } \\
\text { Bound }\end{array}$ & $\begin{array}{l}\text { Upper } \\
\text { Bound }\end{array}$ \\
\hline Constant & -184.105 & 190.1 & & -0.97 & 0.334 & -559.51 & 191.29 \\
\hline Constant weeding & -280.632 & 207.55 & -0.104 & -1.35 & 0.178 & -690.48 & 129.23 \\
\hline Fertiliser application & 74.087 & 241.49 & 0.028 & 0.31 & 0.759 & -402.79 & 550.96 \\
\hline Chemicals & 174.448 & 220.88 & 0.072 & 0.79 & 0.431 & -267.73 & 610.62 \\
\hline Concoctions & 1107.069 & 453.95 & 0.31 & 2.44 & 0.016 & 210.64 & 2003.49 \\
\hline Resistant varieties & 44.189 & 340.41 & 0.013 & 0.13 & 0.897 & -628.01 & 716.34 \\
\hline Phyto-sanitary methods & -1221.23 & 441.6 & -0.342 & -2.77 & 0.006 & -2093.27 & 349.19 \\
\hline
\end{tabular}

a Dependent Variable: change in production. *P-value significantly different at $1 \%$ level of significance

the infected plant $(10.4 \%)$. Other commonly reported control practices were fertiliser application (12.4\%) and planting tolerant varieties mainly local/ traditional varieties $(9.2 \%)$.

Marked variability was reported in the effectiveness of the control methods used, with Phyto-sanitary methods and planting tolerant varieties as the most effective methods, though used by few respondents. The least effective method reported was the use of concoctions (Table 4).

\section{Discussion}

Farmer indigenous knowledge and economic implications of CLR

From the results, majority of respondents $(83.8 \%)$ were aware of CLR and its symptoms (Table 1). The major symptom reported was appearance of pale yellow spots on the lower surface of the leaves. These spots enlarged and produce spores, which were orange/rust in colour, leading to premature defoliation and loss of 
Table 6. Limitations in use of inputs for controlling CLR in Uganda

\begin{tabular}{lc}
\hline Type of limitation & $\begin{array}{c}\text { \% household } \\
\text { reporting limitation }\end{array}$ \\
\hline 1. Poor quality on the market/ counterfeits & 93.6 \\
2. Inadequate capital to use and maintain & 81.5 \\
3. Inputs are expensive to purchase & 43.9 \\
4. Most inputs are not readily available on the market & 27.7 \\
5. Long distances/ high transport costs to input outlets & 20.2 \\
6. No limitation & 15 \\
7. Requires alot of man power like to make organic manure & 4.1 \\
8. Some Inputs like fertilizers don't last for a long time & 2.3 \\
9. Lack of skill/ knowledge on the use of inputs & 31.2 \\
\hline
\end{tabular}

photosynthetic surfaces. According to Hakiza (1997) consequently, the plant resorts to stored carbohydrates in the roots to sustain berry development. This leads to loss of fine feeder roots, thus expanding berries fail to fill up due to lack of required nutrients. Subsequently, the young berries shed off. Infected leaves which remain on the trees provide sources of infection when it rains, thus re-activating the fungus. This is why there is generally a loss of yield even the year after rust outbreaks (Avelino et al., 2004); and the cycle continues until when a control measure is implemented.

Farmers were aware of the disease spread. Moreover, the findings corroborate with earlier reports by Eskes (1983) and Hakiza (1997); relating CLR symptoms and spread directly to prevailing ecological conditions such as rainfall, temperature, duration of leaf wetness and wind velocity. Similarly, other researchers (Malhi and Kutcher, 2004; Avelino et al., 2007) reported that slopes are conducive for epidemics of some fungal diseases such as the American leaf spot, Mycenacitricolor and several leaf spots. High disease incidence is also, in part, attributed to the presence of predominantly susceptible Arabica coffee varieties to CLR; notably, Bugisu local, SL14, KP423 and SL28 (Musoli et al., 2001), which were commonly reported to have been grown by the respondents. Matovu et al. (2013) reported the highest leaf rust incidence in farms on very steep, steep and medium slopes such as Mt. Elgon region. Indeed reports indicate that the disease has spread throughout the districts in Mt. Elgon region in Eastern Uganda. The reduction in yield associated with the spread of the disease led to the rise in Arabica coffee prices by nearly half (New vision, 16 September 2013).

The observations agree with findings of this study that rust incidence in the region led to a significant reduction in Arabica coffee productivity and income by $49.5 \%$. The economic implication from this is that coffee productivity has a profound and significant impact on livelihoods and food security. Researchers have also linked coffee to poverty reduction, asserting that poverty levels in Uganda have been relatively lower in periods when coffee productivity was high and vice versa ${ }^{1}$. Many households go hungry because of food shortage and lack of cash to buy food. A drop in income 
from coffee leads to reduction in cash meant to meet other household requirements such as health and education, investments, social obligations, such as contribution to funeral rights and weddings and hiring of labour. Results indicate that when CLR reduce coffee yields, farmers tend to sell off their food stocks in order to offset revenue shortage from coffee. Despite the increase in income from food crops, there was a general reduction in expenditure on household socio-economic obligations. But when there was no CLR, farmers tended to preserve most of their food stocks as proceeds from coffee covered most of the household requirements (Table 3 ). Therefore, coffee provides the cash needed by the farm households, such that most of the food they produce is reserved for consumption while the cash needed for other socio economic requirements are met from coffee sales. Similar losses due to CLR have been reported by Van der Vossen (2001) and Silva et al. (2006).

\section{Coping mechanisms for CLR}

The majority of farmers to a large extent, had taken efforts to control the disease mainly through cultural measures; while a few were using chemicals (Bordeaux mixture). This may be attributed to the fact that, since most farmers' proceeds from coffee were low, the costs of purchasing chemicals would have a bearing on the profitability of the enterprise. The most effective control methods reported were phyto- sanitary and planting tolerant varieties to CLR (Table 4).

This observation agrees with findings by others (Bock, 1962; Hakiza, 1997; Mouen Bedimo et al., 2007; Bigirimana et al., 2012) who stressed the influence of some agronomic practices such as pruning, mulching, weed management, coffee tree spacing and use of soil amendments, on CLR development. However, while the use of phyto-sanitary methods significantly reduced the impact of the disease on productivity, planting tolerant varieties did not. This may be due to the small number of farmers who planted tolerant varieties, either because the majority was ignorant about the existence of the varieties (Silva et al., 2002; 2008; Guerra-Guimares et al., 2009) or lack access to the varieties. Thus, extension and/or research agents are urged to promote and increase access to resistant materials to CLR.

Farmers who reported using chemicals, mainly used insecticides, mainly Bordeaux mixture and concoctions. Application of such control methods by farmers was reported in literature (Wardell, 1987; Logan et al., 1990; Nkunika, 2002; Nyeko and Olubayo, 2005). However, it was observed that many farmers $(31.2 \%)$ used chemicals without knowing their composition, time of application or frequency of usage (Table 6). They mainly got guidance from fellow farmers without proper technical advice.

Results further show that adulteration was on the rise as many (93.6\%) farmers reported using counterfeits. Pimentel (2005) asserts that the decision by farmers to use chemical measures for controlling insect pests is highly influenced by environmental and human health concerns. Propper et al. (1996) also emphasizes the use of insecticides by coffee farmers in rural Guatemala for combating fungi. Nyeko et al. (2002) found that some farmers in Kabale district in Uganda advised others to use Dithane (fungicide) for combating aphids.

This means that the pesticides would be wasted, resulting in unnecessary and 
potentially harmful health and environmental impacts. Thus, the task for extension and/or agro-input dealers to provide technical advice to farmers on the use insecticides because some of these chemicals are highly toxic (Banjo et al., 2003) and prohibitively costly (Orikiriza et $a l, 2013$ ) and promote more selective, and less dependent use and safer handling of such products (Trutmann et al., 1996). Results further indicate that, though concoctions were used by a few farmers, their influence on the disease was significant.

This calls for further research on the kinds of concoction mixtures being used. Some plant leaves are known to contain fungicides. Such a control method, once validated and improved by scientists could be easier and more affordable to farmers.

\section{Acknowledgement}

This study is a result of a collaborative project funded by Common Funds for Commodities (CFC), through CABI and supervised by International Coffee Organization (ICO). The management of NARO/ NaCRRI and NaCORI for providing logistical facilities

\section{References}

Armstrong, R.A. and Eperjesi, F. 2001. The use of data analysis methods in optometry: Comparing the difference between two groups. OT 412:27 - 31 .

Aniku, J.R.F. 2001. Soil classification and pedology.In Agriculture in Uganda. In: Mukiibi, J.K. (Ed.). Fountain Publishers/CTA/NARO I:66-103.

Avelino, J., Cabut, S., Barboza, B., Barquero, M., Alfaro, R., Esquivel, C., Durand, J.F. and Cilas, C. 2007. Topography and crop management are key factors for the development of American leaf spot epidemics on coffee in Costa Rica. Phytopathology 97(12):1532-1542.

Avelino, J., Zelaya, H., Merlo, A., Pineda, A., Ordonez, M. and Savary, S. 2006. The intensity of a coffee rust epidemic is dependent on production situations. Ecological Modelling 197(3-4):431447.

Avelino, J., Willocquet, L. and Savary, S. 2004. Effects of crop management patterns on coffee rust epidemics. Plant Pathology 53(5):541-547.

Bigirimana, J., Njoroge, K., Gahakwa, D. and Phiri, N.A. 2012. Incidence and severity of coffee leaf rust and other coffee pests and diseases in Rwanda. African Journal of Agricultural Research 7(26):3847-3852.

Bock, K.R. 1962. Seasonal periodicityof coffee leaf rust and factors affecting the severity of outbreaks in Kenya colony. Transactions of the British Mycological Society 45:289-300.

CAB International. 2006. Pests and diseases of coffee in East Africa: A Technical and Advisory Manual. CAB International, Walling Ford UK Compiled and edited by Mike Rutherford and Noah Phiri.

Eskes, A.B. and Dacosta, W.W. 1983. Characterization of incomplete resistance to Hemileia vastatrix in the Icatu coffee population. Euphytica 32:649-657.

Guerra-Guimares, L., Silva, M.C., Struck, C., Loureiro, A., Nicole, M., Rodrigues, C.J. and Ricardo, C.P.P. 2009. Chitinases of Coffea arabica genotypes resistant to orange rust Hemileia vastatrix. Biologia Plantarum 53(4):702-706.

Hakiza, G.J. 1997. Characterization of the epidemiology of coffee leaf rust caused 
by Hemileia vastatrix on robusta coffee (Coffea canephora) in Uganda. PhD. Department of Agriculture, University of Reading, February, 1997.

Kathuri, N.J. and Pals, D.A. 1993. Introduction to educational research. Egerton University, Njoro Kenya: Education Materials Center.

Kushalappa, A.C. and Eskes, A.B. (Eds.).1989. Coffee rust, epidemiology and control. CRC Press, Inc. Boca Raton, Florida, USA.

Logan, J.W.M., Cowie, R.H. and Wood, T.G. 1990. Termites (Isoptera) control in agriculture and forestry by nonchemical methods: a review. Bulletin of Entomological Research 80:309 330.

Malhi, S.S. and Kutcher, H.R. 2004. Effect of topography, $\mathrm{N}$ fertilization and fungicide application on leaf spot diseases, yield and seed quality of wheat in North-Central Saskatchewan. Proceedings of the 7th International Conference on Precision Agriculture and other Precision Resources Management, Hyatt Regency, Minneapolis, MN, USA, 2528 July, 2004. pp. 1008-1015.

Matovu, R., Kangire, A., Phiri, N.A., Hakiza, G.J., Kagezi, G.H. and Musoli, P.C. 2013. Ecological factors influencing incidence and severity of coffee leaf rust and coffee berry disease in major Arabica coffee growing districts of Uganda. Uganda Journal of Agricultural Sciences 14(1):87 - 100.

Mouen Bedimo, J.A., Bieysse, D., Njiayouom, I., Deumeni, J.P., Cilas, C. and Nottéghem, J.L. 2007. Effect of cultural practices on the development of Arabica coffee berry disease, caused by Colletotrichum kahawae.
European Journal of Plant Pathology 119(4):391-400.

Musoli, P.C., Hakiza, G.J., Birinkunzira, J.B., Kibirige-Sebunya and Kucel, P. 2001. Coffee (Coffea spp.). In: Agriculture in Uganda Vol. II. Mukiibi, J.K. (Ed.). pp. 376-436. Fountain Publishers/CTA/NARO. Kampala, Uganda.

Nkunika, P.O.Y. 2002. Smallholder farmers' integration of Indigenous Technical Knowledge (ITK) in maize Integrated Pest Management (IPM). A case study in Zambia. Insect Science and its Application 22(3):235 - 240.

Nyeko, P., Edwards- Jones, G., Day ,R.K. and Raussen, T. 2002. Farmers' knowledge and perceptions of pests in agroforestry with particular reference to Alnus species in Kabale district, Uganda. Crop Protection 21:929 - 941

Nyeko, P. and Olubayo, M.F. 2005. Participatory assessment of farmers' experiences of termite problems in agroforestry in Tororo district, Uganda. Agricultural Research \& Extension Network Paper No. 143. 16pp.

Orikiriza, J.B., Nyeko, P. and Sekamatte, B. 2003. Farmers' knowledge, perceptions and control of pestiferous termites in Nakasongola district, Uganda. Uganda Journal of Agricultural Sciences 13 (1):71-83

Silva, M.C., Guerra-Guimaraes, L., Loureiro, A. and Nicole, M.R. 2008. Involvement of peroxidases in the coffee resistance to orange rust (Hemileia vastatrix). Physiological and Molecular Plant Pathology 72(1-3):29-38.

Silva, M.C., Varzea, V., Guimaraes, L.G., Azinheira, H.G., Fernandez, D., Petitot, A.S., Lashermes, P., Nicole, M. and 
Farmer awareness, coping mechanisms and economic implications

Bertrand, B. 2006. Coffee resistance to the main diseases: Leaf rust and coffee berry disease. Brazilian Journal of Plant Physiology 18(1):119-147.

Silva, M.C., Nicole, M., GuerraGuimaraes, L. and Rodrigues, C.J. 2002. Hypersensitive cell death and post-haustorial defence responses arrest the orange rust (Hemileia vastatrix) growth in resistant coffee leaves. Physiological and Molecular Plant Pathology 60(4):169-183.

Small, W. 1928. The diseases of coffee arabica in Uganda. Government Press Uganda F.L.S. pp. 6-11. Department of agriculture, Kampala, Uganda.

Stephen, A. Ferreira, 1991. Crop knowledge master. Ann. Appl. Biol., 87: 97-103.

UCDA (Uganda Coffee Development Authority). 2011. UCDA Monthly report. (www.ugandacoffee. org/ resources/12-September_2011 rpt.pdf )

Van der Vossen, H.A.M. 2001. Coffee breeding practices. In: Clarke, R.J. and Vitzthum, O.G. (Eds.). Coffee Recent Developments. Oxford: Blackwell Science. pp. 184-201.

Van Asten, P.J.A., Wairegi, L.W.I., Mukasa, D. and Uringi, N.O. 2011. Agronomic and economic benefits of coffee-banana intercropping in Uganda's smallholder farming systems. Agricultural Systems 104:326-334.

Wardell, D.A. 1987. Control of termites in nurseries and young plantations in Africa: established practices and alternative courses of action. Commonwealth Forestry Review 66: 77 - 89. 